\title{
Skills of Students Asking in Learning Clasical Format
}

\author{
*Nurfarida Deliani ${ }^{1}$, Prayitno ${ }^{2}$, A. Muri Yusuf ${ }^{2}$, and Jamaris Jamna ${ }^{3}$ \\ ${ }^{1}$ Doctor Program of Education Science, Universitas Negeri Padang, Indonesia. \\ ${ }^{2}$ Department of Guidance and Counseling, Universitas Negeri Padang, Indonesia. \\ ${ }^{3}$ Department of Non Formal Education, Universitas Negeri Padang, Indonesia. \\ Email : sarifahaura@gmail.com
}

*Corresponding Author, Received: Februari 10, 2019, Revised: April 10, 2019, Accepted: May 10, 2019

\begin{abstract}
Learning is characterized by the use of good questioning skills, especially in learning for large groups of children. Skills in question play an important role in student learning activities. The low skill of students asking in the learning process can lead to disruption of an effective learning process and must be handled by the BK teacher appropriately. Questions are one of the stimuli of thinking that is good for teaching students. The research method used is $R \& D$ (Research and Development) by following the steps in developing the ADDIE pattern (Analyze, Design, Development, Implementation, Evaluation). The subject of the research trial consisted of experts to test the feasibility of the model, the BK teacher to assess the suitability of the model, and students to test the effectiveness. The study was conducted by collecting initial data as a material for consideration in preparing the initial model which was then tested for its suitability and effectiveness through Focus Group Discussion (FGD) and expert testing. The results of this study show that the students' skills in question are in the high category.
\end{abstract}

Keywords: Student Skills to Ask, Classical Format

\section{Introduction}

Asking questions in the learning process plays an important role. Questions are one of the stimuli of thinking that is good for teaching students. Good learning is characterized by the use of good questioning skills, especially in learning for large groups of children. Good questions can stimulate children's curiosity, stimulate children's imagination and motivate children to acquire new knowledge. The more skilled in asking, the more curiosity students have developed (Hosnan, 2014). The questioning skill is a way of delivering a lesson through two-way interaction, namely from the teacher to students and from students to the teacher in order to obtain answers to material certainty through verbal answers (Abimayu, 2007). Questions can challenge students to think, help them clarify concepts and problems related to learning. The question also shows the critical power of the child as stated by Fakhruddin (2009) that through asking occurs the process of constructing the mind and heart to determine a wise solution that can be actualized for the benefit and benefit of all people.

For students the questioning activity is an important part in carrying out discovery-based learning (inquiry) that is digging up information, confirming what has been studied and directing attention to aspects that have not been known (Trianto, 2009). Pierce (1978) explains in the learning process, asking is seen as a teacher's activity to encourage, guide and assess students' thinking skills. For students the questioning activity is an important part in carrying out discovery-based learning (inquiry) that is digging up information, 
confirming what has been studied and directing attention to aspects that are not yet known. To assess the effectiveness of learning and the effectiveness of children's learning abilities (Pierce, 1978). Through asking the teacher can see whether the learning done is effective or not. This fact is corroborated by observations in a study conducted by Yunus (2013) that students' learning skills and questions on Indonesian subjects were very low. This is because the teacher only teaches subject matter to students.

Students who have questions of skill problems, can get treatment from professional staff, namely counselors or counselors as early and optimally as possible. In school counselors can use 10 types of counseling services, to realize the goals of guidance and counseling in the learning process, namely service orientation, information, placement and distribution, content mastery, group guidance, group counseling, individual counseling, mediation, consultation, and advocacy. All types of services are very useful in alleviating various learning problems experienced by clients, one of which is content mastery service (PKO). PKO service in guidance and counseling aimed at individuals master the aspects of certain content synergistically. Prayitno, (2017) explains the meaning of PKO Services is a service of assistance to individuals (individually or in groups) for master certain abilities or competencies through activities learn.

Student activities in the classroom, in learning can be said to only listen to the teacher's explanation, record things that are considered important, and answer questions if appointed. There are also some students who are sleepy, lazing and doing activities that have nothing to do with learning. In other words the implementation of the scientific approach in learning is still difficult. In addition, students' asking skills are very low. Students rarely ask questions to the teacher during the learning process. When asked questions to them, almost all students do not dare raise their hands to answer. Conversely, if given the opportunity to ask, there are rarely students who use it. They look scared (not brave) asking questions/opinions about the material presented. This problem if you do not get the right treatment will hinder the process of education that they follow at the school. The existence of these obstacles can result in students being difficult to follow learning activities optimally.

\section{Method}

Type of research is Research\&Development (R\&D). The study population was class X MAN 2 Padang 2016/2017 academic year amounting to 40 students, Data obtained in this study were quantitative data and qualitative data. Quantitative data obtained from questionnaires and qualitative data obtained from the results of focus group discussion (FGD), observation, interviews. The type of data taken in this study is primary data obtained directly from students and BK teachers. Each type of data and instruments are in accordance with the objectives of each research stage in the framework of implementing ADDIE.

\section{Result and Discussion}

Data in this study include skill variables students ask in classical format learning. The following is a description of the research data. Analysis of the Condition of Student Skills Asking Students in Classical Format Learning in MAN 2 Padang.

Table 1. Condition of Student Skills Asking Students in Classical Format Learning in MAN 2 Padang.

\begin{tabular}{|c|c|c|c|c|c|c|}
\hline \multirow{2}{*}{ Criteria Frequency } & \multicolumn{5}{|c|}{ Indicator } & \multirow[b]{2}{*}{ Sum } \\
\hline & $\mathbf{A}$ & $\mathbf{B}$ & $\mathrm{C}$ & D & $\mathbf{E}$ & \\
\hline Very High $84 \%-100 \%$ & - & - & - & - & - & \\
\hline Average $52 \%-67 \%$ & 1,3 & $6,8,10$ & 13,15 & 16,18 & 22,23 & 11 \\
\hline Low $36 \%-51 \%$ & 4,5 & 9 & 14 & & 24,25 & 6 \\
\hline Very Low $20 \%-35 \%$ & 2 & 7 & 11,12 & $17,19,20$ & 21 & 8 \\
\hline
\end{tabular}

Table. 1 It can be concluded that the skills of students asking in classical format learning must be handled by the BK teacher so that the learning process of the students in the classroom will be more qualified. Stage Based on the data in the analysis phase, a PKO service model was developed in the form of a 
guidebook for BK teachers. The details of the results of data analysis can be interpreted to show that there is an alignment/ appropriateness of the assessment of the five experts on the research product from the aspect of the guidebook. The details of the results of data analysis can be interpreted indicating that the model and guidebook are feasible and can be used by BK teachers. the value of 40a means that of the 40 respondents in the experimental group involved in the calculation, as many as 40 students experienced an increase from pretest to posttest. Based on the results above, it can be seen that students' skills in asking students before and after being given PKO services have increased. Of the 40 students who were given the PKO service model to improve the skills of students asking by BK teachers, all students (40 people) experienced an increase with an average increase of 20.5 .

Gage and Berliner (1983) state that learning is the process by which an organism changes its behavior because of the results of experience. Slavin (1994) states that learning is a change in students caused by experience. Learning is a process that is considered important for changing the behavior of each person and learning includes everything that someone thinks and does. It is also the action most people do. As a term of psychology and education, learning is what in English the term is learning, not studying. The general definition of learning is referring to the occurrence of changes in a person, namely changes in behavior through experience. Djamarah (2002) explains the notion of learning: "A series of mental and physical activities to obtain a change in behavior as a result of students' experience in interaction with their environment which involves cognitive, affective and psychomotor".

In accordance with the above opinion, Slameto (2013) also stated that learning is a business process carried out by a person to obtain a change in new behavior as a whole, as a result of his own experience in interaction with his environment. To get something someone must make an effort so that what is desired can be achieved. The business can be either independent or group work in an interaction. Furthermore Muhibbinsyah (2009) explains, learning is a process of gaining knowledge and experience in the form of changes in behavior and abilities in relatively permanent or permanent action, because of the existence of students with their environment. Furthermore, students' asking skills in the learning process can be influenced by certain factors. Students' asking skills that are low if left alone will have an impact on the process and student achievement in school. The initial findings of the study illustrate that the lowest average score of questioning skills is $74 \%$ of students who rarely memorize questions before asking the teacher, $77 \%$ of students also rarely record friend questions, $80 \%$ feel disappointed if the teacher has not been appointed. Improving the quality of asking students will have a considerable impact on the active learning process. Questioning skills have a positive impact on the learning process, namely: 1) can increase student participation in full in the learning process, 2) can improve students 'thinking abilities, because thinking itself in essence asks, 3) can arouse students' curiosity, and guide students to determine answers, 4) focus students' attention on the problem being discussed. Important things that must be considered in asking are: 1) the objectives to be achieved from the method of asking, 2) the types of questions, there are two questions that need to be. Usually this question starts with the word why, and how. The process of asking strongly puts forward the process of critical thinking of a human being. Thinking and managing his behavior are not merely objects that are always victims of the environment. Based on the description above, it is clear that each student has the potential that he can develop and be guided by the teacher. So that the teacher acts as a good guide.

Implementation of this model so that BK teachers can teach and train new abilities to students to be more courageous to speak, express opinions and ask questions during the learning process. For this reason, a guidebook and a companion book are needed for the PKO service model as a reference material and reference for the BK teacher in training and improving students' asking skills. The development of this PKO service model, is considered to be able to be done by the BK teacher / counselor to improve students' skills in asking, because of PKO services aims to train students in mastering certain aspects of synergic content. PKO services are assistance services to individuals (individually or in groups) for master certain abilities or competencies through activities learn. The ability or competition that is learned is a unit of content which contains facts and data, concepts, processes, laws and rules, values, perceptions, affections, attitudes and actions related to it. With content mastery services, individuals are expected to be able to meet their needs and overcome their problems. Through the content mastery service it is also able to help individuals master the aspects of the content in synergy, including the skills students ask in the learning process in the classroom. 
The purpose of PKO services, is also related to the functions of guidance and counseling services, namely: a) The function of understanding, concerning content in classical learning formats that need to be mastered. In this case all aspects of content (i.e. facts, data, concepts, processes, laws, rules, values, and even aspects related to perception, affection, attitudes and actions) require an understanding of the content that is the focus of PKO services, b) Prevention function, it can be a PKO service charge if the content is directed towards avoiding individuals or clients from experiencing certain problems or KES-T (Daily life is interrupted). This is related to the prevention of students from being problematic, so that the achievement of KES development and handling of KES-T, c) The alleviation function, will be the direction of service if the content mastery is to overcome the problem (KES-T) that the client is experiencing. The function of development and maintenance, can directly or indirectly develop on the one hand, and on the other hand maintain the potential of individuals or service targets. (d) The function of advocacy, with the mastery of targeted content allows individuals to defend themselves against threats or violations of their rights.

The results of the implementation of the PKO service model in addition to improving students' asking skills, also provide opportunities for students to commit to always practice it in all subjects. The benefits of increasing this questioning skill can be felt in all learning processes. The PKO service model to improve students' questioning skills in classical format learning is arranged in the form of guidebooks and companion books. The guidebooks and companion books for the PKO service model that have been compiled and evaluated must be trained beforehand for the BK teacher to be implemented. The training process is given to BK teachers who have been recommended by the school. This is in line with the National Education System Law of 1989, emphasizing that education is carried out in the form of guidance, teaching and training. The implementation of the PKO service model implementation by the BK teacher turned out to get a very positive response from students. This is because the problem of students' asking skills very often occurs during the learning process, so the provision of this service model is very helpful for students in developing the potential and skills to ask the teacher. So from that the increase in students' questioning skills is very important to be mastered by students in order to be able to provide responses in accordance with the stimulus given by the teacher in the learning process in the classroom.

The development of the PKO service model and its implementation has been carried out in the State Madrasah Aliyah (MAN) 2 in Padang City with the ADDIE pattern. But the development of this model also has development limitations outlined as follows: The implementation of the model developed is only located in MAN 2, Padang City, given the limited time and opportunity available to researchers. This model needs to be developed at all levels and types of education. The implementation of the PKO service model has only been implemented for a limited period of time, so that the increase in student questioning skills has not been optimal. This requires the implementation of sustainability to get more optimal results. This study has not controlled all the factors that are likely to affect the physical and psychological condition of students, such as gender, level of intelligence, health, maturity, values and teaching from parents, which can affect the results of the implementation of the PKO service model .

\section{Conclusion}

Direction of this study is the use of PKO service models to improve the skills of students asking in classical format learning. The condition of the PKO service model produced by this researcher and its effectiveness in improving the skills of students asking in classical format learning. The results of the study found that the quality of counseling teachers in improving students' asking skills was improved. This is because the service content mastery is not maximized so that there are special models that can improve students' skills in asking. BK services in the classical format are only 1 lesson per week in each class and the number of BK teachers is only 2 people out of a total of 1400 students. Service model was compiled a guidebook containing: (1) rational and content mastery service content (PKO) to improve students' skills in asking, (2) PKO service readiness and implementation, and (3) PKO service implementation tools. Results of the study show that the PKO service model that was trained and implemented to the BK teacher as contained in the guidebook and companion book, is in the category of feasible content and practice or implementation by the BK teacher. 


\section{References}

Abimanyu, S. 2007. Strategi Pembelajaran. Jakarta: Depdiknas.

Djamarah, S. B. 2002. Psikologi Belajar. Jakara: Rineka Cipta.

Fakhruddin, A. U. 2009. Menjadi Guru Favorit. Jogyakarta: Diva Press.

Gage, N. L., and Berliner, D. C. 1994. Pedagogine Psichologija. Alna Litera.

Hosnan 2014.Pendekatan Saintifik dan Konstektual dalam Pembelajaran Abad 21, Jakarta: Ghalia Press.

Muhibbin, S. 2003. Psikologi Pendidikan dengan Pendekatan Baru. Bandung: Remaja Rosdakarya.

Pierce, C. M. 1978. Television and Education.Vol. 44. Sage Publications, Inc..

Prayitno. 2017. Konseling yang Berhasil. Jakarta: Ghalia Press.

Slameto, 1996. Belajar dan Faktor-Faktor yang Mempengaruhinya. Jakarta: RinekaCipta.

Slavin, E. R. 1994. Education Psychology Theory and Practice. Needham.

Trianto. 2012. Mendesain Model Pembelajaran Inovatif-Progresif, Jakarta: Kencana Prenada.

Yunus, M., Marli, S., and Kresnadi, H. 2013. Peningkatan Keterampilan Bertanya Siswa dengan Menggunakan Media Audio pada Pembelajaran Bahasa Indonesia. Jurnal Pendidikan dan Pembelajaran, 2(4). 